Note

\title{
FEEDING SITE OF THE SPITTLEBUG Mahanarva fimbriolata (STÅL) (HEMIPTERA: CERCOPIDAE) ON SUGARCANE
}

\author{
José Francisco Garciaㄹ; Eliane Grisotoํㅜ Paulo Sérgio Machado Botelho²*; José Roberto \\ Postali Parra ${ }^{3}$; Beatriz Appezzato-da-Glória ${ }^{4}$ \\ ${ }^{1}$ USP/ESALQ - Programa de Pós-Graduação em Entomologia Agrícola. \\ ${ }^{2}$ UFSCar/CCA - Depto. de Biotecnologia Vegetal - C.P. 153 - 13600-970 - Araras, SP - Brasil. \\ ${ }^{3}$ USP/ESALQ - Depto. de Entomologia, Fitopatologia e Zoologia Agrícola - C.P. 09 - 13418-900 - Piracicaba, SP - \\ Brasil. \\ ${ }^{4}$ USP/ESALQ - Depto. de Ciências Biológicas - C.P. 09 - 13418-900 - Piracicaba, SP - Brasil. \\ *Corresponding author < pbotelho@cca.ufscar.br>
}

\begin{abstract}
The sugarcane spittlebug Mahanarva fimbriolata (Stål) (Hemiptera: Cercopidae) is a pest of mechanically-harvested sugarcane in Brazil, when trash burning is not performed. To better understand the differences in feeding behavior of adults and nymphs of this pest and the subsequent disorders that arise, stylet penetration through fixation, staining and sectioning was investigated. Nymphs cause a "physiological disorder" damaging the tracheary system of the roots, slowing or preventing water and nutrient flow, with phloem and xylem dehydration. Nymphs insert their stylets through the epidermis, crossing the cortex, endodermis and pericycle before reaching the vascular cylinder, where they feed in the sieve-tube elements of the primary phloem. In contrast, adults feed on leaves, causing "sugarcane burn", and reducing plant photosynthesis. Adults introduce the stylets into the leaf blade through the stomata, passing the chlorophyll-bearing parenchyma cells before reaching the metaxylem in the vascular bundles.

Key words: anatomy, insect-plant interaction, salivary sheath, vascular tissue

\section{SÍTIO DE ALIMENTAÇÃO DE Mahanarva fimbriolata (STÅL) (HEMIPTERA: CERCOPIDAE) EM CANA-DE-AÇÚCAR}

\begin{abstract}
RESUMO: Atualmente, a cigarrinha-das-raízes, Mahanarva fimbriolata (Stål) (Hemiptera: Cercopidae), é a principal praga da cana-de-açúcar colhida mecanicamente, sem a queima da palha. As ninfas causam a "desordem fisiológica” em decorrência das picadas que atingem os elementos traqueais da raiz e os deterioram, dificultando ou impedindo o fluxo de água e de nutrientes, caracterizado pela desidratação do floema e do xilema. Ao contrário das ninfas, os adultos alimentam-se nas folhas e ocasionam a "queima da cana-de-açúcar”, conseqüência das toxinas, injetadas ao se alimentar, reduzindo sensivelmente a capacidade de fotossíntese da planta. As ninfas de $M$. fimbriolata, para sugarem a seiva nas raízes, inserem seus estiletes pela epiderme, atravessam todo o córtex e atingem o cilindro vascular, realizando a alimentação nos elementos do tubo crivado do floema primário. Na lâmina foliar, os adultos de $M$. fimbriolata introduzem seus estiletes preferencialmente pelos estômatos, atravessam as células do parênquima clorofiliano e atingem o metaxilema nos feixes vasculares.

Palavras-chave: anatomia, interação inseto-planta, bainha salivar, floema e xilema
\end{abstract}

\section{INTRODUCTION}

In recent years, due to changes in the sugarcane harvesting practice, with trash no longer burned, a significant increase in populations of Mahanarva fimbriolata (Stål) has been observed in the São Paulo State, Brazil.

There is little information about the feeding site of cercopids on this host plant. However, adults of the cercopid Aeneolamia varia saccharina (Distant) introduce their stylets through the stomata of leaves and not directly through the epidermis, then passing through several leaf tissues to reach the cells on the edge of the leaf parenchyma. Nymphs feed directly on proto- and metaxylem elements in the roots. During the first instars, nymphs also feed on parenchyma cortex cells of young roots. When this occurs, the stylets generally reach the endodermis or the pericycle. Fifth- 
instar nymphs reach root xylem elements (Hagley \& Blackman, 1966).

The feeding behavior of nymphs of the cercopid Philaenus spumarius (L.), as verified by Horsfield (1978), involves most feeding punctures reaching the xylem vessels. The parenchyma cells around the stylet sheath do not show necrosis, and the large production of feces supports the conclusion that the insect feeds on those conducting vessels. Of all stylet sheath terminations, only $9 \%$ reached phloem vessels.

Adults feed on leaves and nymphs on roots, and no reference was found in the literature on the feeding sites of $M$. fimbriolata on sugarcane. Therefore, the objective of this study was to determine where feeding terminated internally for $M$. fimbriolata adults and nymphs, on sugarcane.

\section{MATERIAL AND METHODS}

The research was carried out in Piracicaba,

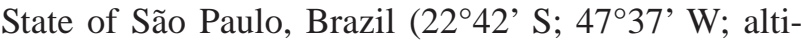
tude $546 \mathrm{~m}$ ), with spittlebugs obtained from a laboratory colony kept as described by Garcia et al. (2006,
2007). One adult per plant was caged in screened boxes $(5.5 \times 4.0 \times 2.0 \mathrm{~cm})$ attached to sugarcane leaves cv. SP 80-1842, and one nymph per plant (3rd instar) was maintained on roots. Both plants and insects were maintained at $25 \pm 1{ }^{\circ} \mathrm{C}$, RH $70 \pm 10 \%$, and on a 14 hour - light cycle. There were six replications for each set (adult/plant and nymph/plant).

Leaf fragment $(\mathrm{N}=6)$ and $\operatorname{root}(\mathrm{N}=6)$ samples on which feeding had occurred for 24 hours were fixed in Karnovsky solution (Karnovsky, 1965), dehydrated in an ethyl alcohol series, infiltrated in methacrylate resin (Leica), and transversely sectioned. The $5 \mu \mathrm{m}$ thick sections were stained with toluidine blue (Sakai, 1973) and mounted on "Entellan" synthetic resin. Photomicrographs of the slide-mounted materials were prepared on a photomicroscope (Leica DM LB / DC 300 F), with the micrometric scales photographed and enlarged under the same optical conditions.

The $\mathrm{pH}$ of the honeydew liberated by nymphs $\left(3^{\text {rd }}\right.$ instar) was also evaluated. The experimental design consisted of ten replicates, being each made of 15 nymphs, totalizing 150 individuals. The nymphs were isolated from the radicular system of the sugar-
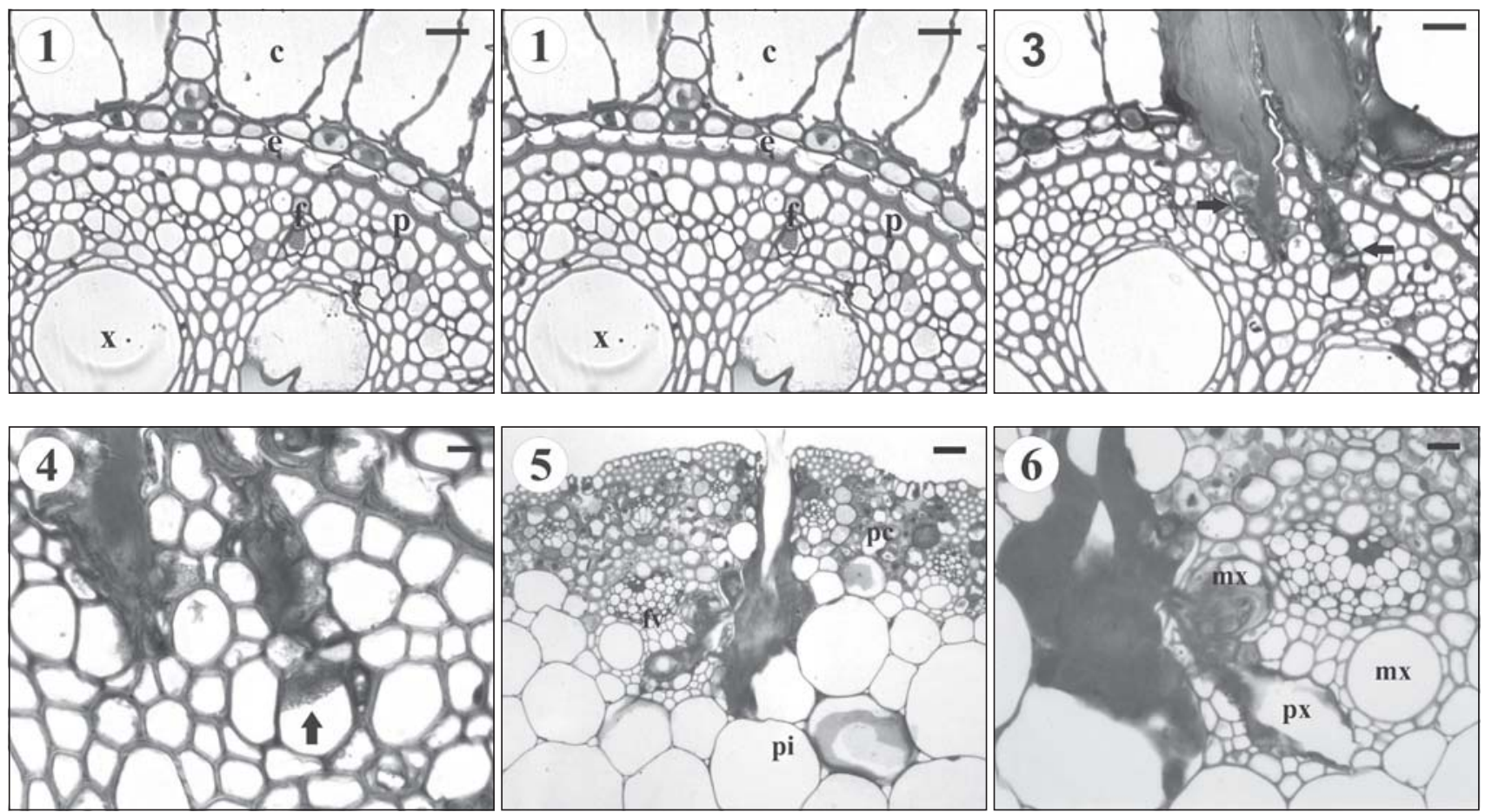

Figures 1-6 - Transverse sections of sugarcane (Saccharum officinarum L.) root (1-4) and leaf (5-6). 1) Observe the cortex (c), endodermis showing a U-shaped reinforcement (e), pericycle (p), primary phloem (f) and xylem $(\mathrm{x})($ Bar= $19 \mu \mathrm{m}) .2)$ Detail from previous figure; observe part of a sieve-plate in a sieve-tube element (arrow) (Bar= $7.4 \mu \mathrm{m})$. 3) Observe the nymphal stylet sheath passing through the cortex, endodermis, pericycle and terminating in the phloem (Bar= 19 $\mu \mathrm{m}) .4)$ Detail from previous figure; observe part of a sieve-plate (arrow) (Bar= $7.4 \mu \mathrm{m})$. 5) Stylet insertion of adults between the stoma guard-cells, and stylet sheath passing through the chlorophyll parenchyma (pc) and clear parenchyma (pi) until the vascular bundle (fv) is reached (Bar= $37 \mu \mathrm{m})$. 6) Stylet sheath termination reaching the proto (px) and metaxylem (mx) (Bar= $19 \mu \mathrm{m})$. 
cane plant, which was inserted in an esterilized jug served as a collector for the honeydew. These nymphs were exposed to roots for $24 \mathrm{~h}$. The determination of the $\mathrm{pH}$ was accomplished with a digital device, Marte make, Model MB10.

\section{RESULTS AND DISCUSSION}

On the roots (Figures 1-4), M. fimbriolata nymphs inserted the stylet through the epidermis, passing through the cortex, reaching the vascular cylinder. Nymphs reached the root xylem vessels suggesting high demand for sap sugar and water at this stage of the life of the insect. Around 35\% of the evaluated nymphs (third-instar) also reached the root phloem. When this happened, they fed on the sieve-tube elements of the primary phloem (Figures 3 and 4). The occlusion of conducting vessels caused root death, due to feeding and mechanical damage caused by the stylets. These observations differ somewhat from those presented by Horsfield (1978) for the species $P$. spumarius and by Hagley \& Blackman (1966) for A. varia saccharina, both of which explore mainly the root xylem, differing only in the percentage of nymphs reaching the root phloem.

Adults introduced their stylets preferentially through the stomata on the leaf blade (Figure 5), passing through the chlorophyll-bearing and clear parenchyma cells and terminating in the metaxylem of the vascular bundles (Figure 6). Considerable mechanical damage occurred, with cell laceration and rupture, compromising the leaf tissue. This behavior is similar to A. varia saccharina, which introduces its stylets through the stomata of sugarcane leaves, passing through several tissues, reaching the cells at the edge of the leaf parenchyma (Hagley \& Blackman, 1966).
The $\mathrm{pH}$ of the phloem sap is around 8.0 (Gerendás \& Schurr, 1999). The average $\mathrm{pH}( \pm$ Standard Error) obtained in this experiment was 7.3 ( \pm 0.38 ), indicating that there is evidence that the nymphs feed on the sieve-tube elements in the primary phloem.

\section{ACKNOWLEDGEMENTS}

To CAPES, for the research scholarship granted to the first author. To FAPESP, for financial support, through project no. 99/08585-9. To Centro de Tecnologia Canavieira - CTC - Piracicaba/SP, for the indispensable supply of sugarcane seedlings.

\section{REFERENCES}

GARCIA, J.F.; BOTELHO, P.S.M.; PARRA, J.R.P. Biology and fertility life table of Mahanarva fimbriolata (Stål) (Hemiptera: Cercopidae) in sugarcane. Scientia Agricola, v.63, p.317-320, 2006.

GARCIA, J.F.; BOTELHO, P.S.M.; PARRA, J.R.P. Laboratory rearing technique of Mahanarva fimbriolata (Stål) (Hemiptera: Cercopidae). Scientia Agricola, v.64, p.73-76, 2007.

GERENDÁS, J.; SCHURR, U. Physicochemical aspects of ion relations and $\mathrm{pH}$ regulation in plants - a quantitative approach. Journal of Experimental Botany, v.50, p.1101-1114, 1999.

HAGLEY, E.A.C.; BLACKMAN, J.A. Site of feeding of the sugarcane froghopper, Aeneolamia varia saccharina (Homoptera: Cercopidae). Annals of the Entomological Society of America, v.59, p.1289-1291, 1966.

HORSFIELD, D. Evidence for xylem feeding by Philaenus spumarius (L.) (Homoptera: Cercopidae). Entomologia Experimentalis et Applicata, v.24, p.95-99, 1978.

KARNOVSKY, M.J. A formaldehyde-glutaraldehyde fixative of high osmolality for use in electron microscopy. Journal of Cell Biology, v.27, p.137-138, 1965.

SAKAI, W.S. Simple method for differential staining of paraffin embedded plant material using toluidine blue. Stain Technology, v.48, p.247-249, 1973.

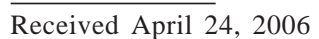

Accepted June 22, 2007 